\title{
Chagasic megacolon: enteric neurons and related structures
}

\author{
Samir Jabari • Enio C. de Oliveira • Axel Brehmer • \\ Alexandre B. M. da Silveira
}

Accepted: 3 July 2014 / Published online: 25 July 2014

(C) The Author(s) 2014. This article is published with open access at Springerlink.com

\begin{abstract}
Megacolon, the irreversible dilation of a colonic segment, is a structural sign associated with various gastrointestinal disorders. In its hereditary, secondary form (e.g. in Hirschsprung's disease), dilation occurs in an originally healthy colonic segment due to an anally located, aganglionic zone. In contrast, in chronic Chagas' disease, the dilated segment itself displays pathohistological changes, and the earliest and most prominent being found was massive loss of myenteric neurons. This neuron loss was partial and selective, i.e. some neurons containing neuronal nitric oxide synthase and/or vasoactive intestinal peptide (VIP) were spared from neuron death. This disproportionate survival of inhibitory neurons, however, did not completely correlate with the calibre change along the surgically removed, megacolonic segments. A better correlation was observed as to potentially contractile muscle tissue elements and the interstitial cells of Cajal. Therefore, the decreased densities of $\alpha$-smooth muscle actin- and c-kitimmunoreactive profiles were estimated along resected megacolonic segments. Their lowest values were observed in the megacolonic zones itself, whereas less pronounced decreases were found in the non-dilated, transitional zones (oral and anal to dilation). In contrast to the myenteric plexus, the submucosal plexus displayed only a moderate
\end{abstract}

S. Jabari · A. Brehmer $(\bowtie)$

Institute of Anatomy I, University of Erlangen-Nuremberg,

Krankenhausstr. 9, 91054 Erlangen, Germany

e-mail: axel.brehmer@fau.de

E. C. de Oliveira

Department of Surgery, Medical School, Universidade Federal de Goiás, Goiânia 74.605-020, Brazil

A. B. M. da Silveira

Human Anatomy Sector, ICBIM, Universidade Federal de

Uberlândia, Uberlândia, MG 38.400-902, Brazil neuron loss. Neurons co-immunoreactive for VIP and calretinin survived disproportionately. As a consequence, these neurons may have contributed to maintain the epithelial barrier and allowed the chagasic patients to survive for decades, despite their severe disturbance of colonic motility. Due to its neuroprotective and neuroeffectory functions, VIP may play a key role in the development and duration of chagasic megacolon.

Keywords Chagas - Enteric nervous system .

Hirschsprung $\cdot$ Megacolon $\cdot$ Vasoactive intestinal peptide

\section{Structural components of the human enteric nervous system}

The overwhelming majority of enteric neuronal cell bodies lie, together with enteric glial cells, in ganglionated nerve networks, the myenteric and the submucosal plexus. These differ in location and network architecture (Fig. 1) as well as in neuronal composition (see below).

Situated between the longitudinal and the circular muscle layer is the myenteric plexus (Auerbach 1862). Its main, primary network is commonly monolayered and extends from the upper oesophageal to the internal anal sphincter.

Most human myenteric neurons are either nitrergic or cholinergic (Murphy et al. 2007; Beck et al. 2009). Like in other species (best known from the guinea pig, Furness 2006), human nitrergic myenteric neurons are suggested to be either descending inter- and/or inhibitory motor neurons (Grider 1993). They are uniaxonal with spiny shaped dendrites (spiny type I morphology; Brehmer et al. 2004a; Lindig et al. 2009). Besides their reactivity for the nitrergic marker neuronal nitric oxide synthase (nNOS), some of them co-stain immunohistochemically for vasoactive 


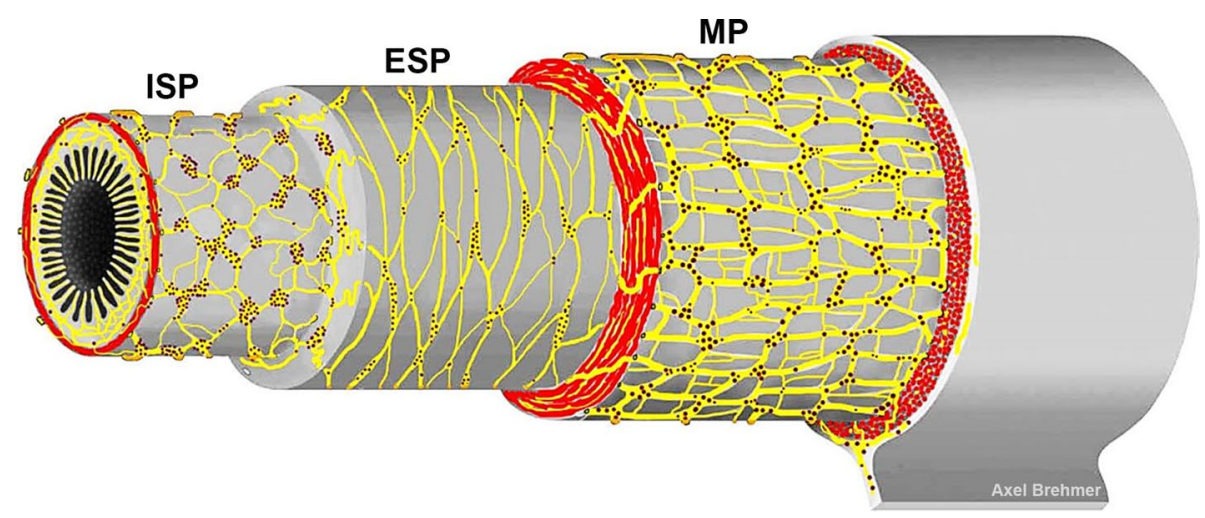

Fig. 1 Schematic drawing of the three ganglionated plexus of the human enteric nervous system, depicted in layer preparation (red: cross-sectioned muscle layer profiles). The different network architectures were approached from numerous original small and large intestinal wholemount specimens. Between the three ganglionated plexus, there are abundant interconnecting strands. Neurons outside these main ganglionated plexus are common. $M P$ myenteric plexus, ESP external submucosal plexus, ISP internal submucosal plexus intestinal peptide (VIP; Brehmer et al. 2006; Schuy et al. 2011). In contrast, cholinergic myenteric neurons, immunoreactive for the common choline acetyltransferase (cChAT), include primary afferent, inter-, and excitatory motor neurons as mainly known from the guinea pig (Furness 2006). Although we have characterized morpho-chemically some non-nitrergic myenteric neuron types in human intestines (Brehmer et al. 2004a, b, 2005), our knowledge of diverse enteric neuron types in the human gut is still fragmentary (Brehmer 2006).

The submucosa of larger mammals harbours a twoor even multilayered plexus (Meissner 1857) which is restricted to the small and large intestines. In human, two ganglionated submucosal plexus can be distinguished (Brehmer et al. 2010), primarily based on their locations within the submucosal layer and their network architectures. The internal submucosal plexus (reassigned to Meissner) lies in the inner half of the submucosa and is frequently multilayered. The external submucosal plexus (Schabadasch 1930) is situated near the inner border of the circular muscle layer and is rather mono-(occasionally two-) layered. As to their neuronal compositions, we have hitherto found only quantitative differences between the human internal and external submucosal plexus (see below). This is in contrast, e.g., to the pig, where clear qualitative differences between the two submucosal plexus were described (Stach 1977; Timmermans et al. 2001; Kapp et al. 2006).

The great majority of human submucosal neurons is cholinergic. Submucosal nitrergic neurons represent a small minority and are partly even absent from the submucosal plexus (Timmermans et al. 1994; Beyer et al. 2013; Beuscher et al. 2014). Among the cholinergic neurons, there are two separate populations that commonly amount for up to $80 \%$ of human submucosal neurons. The larger population is, in the colon, co-immunoreactive for VIP and calretinin (CALR), and the smaller one for somatostatin (SOM) and, partly, substance P (SP; Kustermann et al. 2011; Beyer et al. 2013; Beuscher et al. 2014). The two populations differ also morphologically: VIP/CALRneurons are dendritic, whereas SOM/SP-neurons are nondendritic and (pseudo)uniaxonal. Both submucosal neuron populations may have multiple functions (see below). Among these, VIP/CALR-neurons may act as secretomotor neurons (Karaki and Kuwahara 2004; Farthing 2006; Margolis and Gershon 2009; Chandrasekharan et al. 2013; Beuscher et al. 2014), and SOM/SP-neurons may be primary afferent (Farthing 2006; Kustermann et al. 2011; Beyer et al. 2013).

\section{Megacolon: secondary versus primary}

Megacolon is the chronic dilation of a colonic segment, irrespective of the location of its origin (Fig. 2). Already, after its first description by Hirschsprung (1888; cited after Howard 1972), several early authors suspected the cause of this congenital form not in the 'megacolon' itself but in the absence of enteric neurons (aganglionosis) in the anally located zone (Bodian et al. 1949; Truelove 1966; Howard 1972). As a consequence, the smooth musculature of the affected segment is in a permanent state of contraction. The resulting stenosis causes stasis of ingesta. Subsequently, adaptive transformation of the orally located, originally healthy colonic segment toward a secondary megacolon (Bodian et al. 1949) evolves.

In contrast, enteric neurodegeneration of an originally healthy (normoganglionic) segment becomes manifest in at least $20 \%$ of patients suffering from Chagas' disease (Köberle 1968). During its chronic phase, (my)enteric neuron loss and irreversible dilation occur in one and the same 

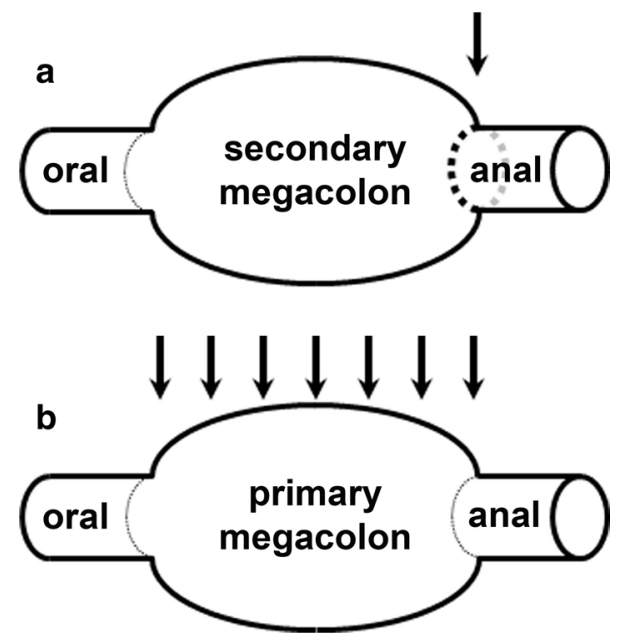

Fig. 2 Two alternate ways for the development of megacolon. a Secondary megacolon (e.g. in Hirschsprung's disease) is due to permanent stenosis of an aganglionic segment (arrow) followed by stasis and secondary inflation of an originally healthy segment. b Primary megacolon (e.g. in Chagas' disease) is due to inflation of the originally diseased segment itself (arrows indicate the zone of an acquired hypoganglionosis)

(frequently colonic) gut segment. Since cause and effect are at the same place, this dilation may be termed as primary megacolon. At the latest since Köberle, (my)enteric neuron loss was commonly considered as the cause for chagasic megacolon: '...denervation is the absolutely indispensable element for the appearance of these (chagasic megacolonic) syndromes...' (Köberle 1968).

During the 1960s, when Köberle and others searched for pathohistological alterations in colonic (and other) megasyndromes, the enteric nervous system (ENS) awaited its conceptual renaissance (Brehmer et al. 1999). Primarily based on works in the guinea pig, the unique position of the ENS within the peripheral nervous system as well as the complexity of its internal organization and external relationships with surrounding tissues and systems was realized (reviewed in Furness and Costa 1987; Furness 2006). These advances in our understanding of the ENS were scarcely accompanied by advances in the explanation of the development of (chagasic) megacolon.

The above, classical explanations for Hirschsprung's megacolon on the one hand (regional absence of enteric neurons leads to permanent contraction of adjacent smooth muscle) and Chagas' megacolon on the other hand (regional absence of enteric neurons leads to permanent dilation of adjacent smooth muscle) are contradictory. In addition, a further, less considered phenomenon requires explanation. The ENS regulates not only motor but also mucosal functions, a vital one being the maintenance of the epithelial barrier of the mucosa. In patients suffering from chagasic megacolon for decades, this barrier should be largely intact which indicates that certain components of the ENS should be undamaged as well. This led us to analyse the fate of different subgroups of enteric neurons and of some of their related structures in chagasic megacolonic segments.

\section{Evaluation of enteric nervous tissue, interstitial cells of Cajal, and smooth musculature}

The enteric nervous tissue consists of neuronal and glial components. To estimate quantitatively their representation in our wholemount and section specimens, we used general and specific immunohistochemical markers.

As marker for demonstrating neuronal cell bodies, the human neuronal protein Hu C/D (HU; Phillips et al. 2004; Ganns et al. 2006) is well established. In contrast, an immunohistochemical pan-axonal marker is, to our knowledge, not generally established. Here, we used synaptophy$\sin (\mathrm{SYN})$ which is specific for synaptic vesicles (Wiedenmann and Franke 1985; Dzienis-Koronkiewicz et al. 2005). Furthermore, specific neuronal markers were applied (see above: CALR, cChAT, nNOS, SOM, VIP).

As marker for the evaluation of changes of the glial component of the enteric nervous tissue, we used the calciumbinding protein S100 (Ferri et al. 1982; da Silveira et al. 2009). In addition to their 'classical' role as pure supporting cells, a number of specialized functions were recently attributed to enteric glial cells, e.g. support of the epithelial barrier function, modulation of neurotransmission, neurogenesis, etc. (Gulbransen and Sharkey 2012).

Interstitial cells of Cajal (ICCs) have been demonstrated by immunolabelling of the c-kit receptor (Huizinga et al. 1995; Vanderwinden et al. 1996; Takaki 2003; Blair et al. 2012), which is located in both ICCs and mast cells but not in enteric neurons (Maeda et al. 1992). ICCs are considered as pacemakers of motility and mediate the input of neurons to the muscularis propria (Thuneberg 1982; Rumessen and Thuneberg 1996; Ward et al. 2004) although this role has also been disputed (see below).

To enable conclusions as to the amount of potentially contractile smooth muscle tissue within the thickened muscle layers, we applied $\alpha$-smooth muscle actin (SMA) as marker for gut musculature (Wedel et al. 2006). In detail, we estimated the smooth muscle density as stained SMAprofile area related to the muscle layer area in cryosections through the gut wall.

\section{Chagasic megacolon: myenteric neurons and intramuscular nerve fibres}

Pathohistological changes obvious in myenteric wholemount specimens of chagasic/megacolonic tissues appear 
as prototypic signs of degeneration which were most distinct in the dilated megacolonic and the anal (non-dilated) region (Jabari et al. 2011). Similar alterations have earlier been demonstrated, by applying various methods, in colonic specimens derived from quite different diseases and from aged colon (De Biscop 1949; Smith 1972; Schuffler et al. 1978, 1985; Schuffler and Jonak 1982; Krishnamurthy et al. 1985; Phillips et al. 2003; Hanani et al. 2004). Instead of myenteric ganglia containing numerous neurons, networks of bulky fibre bundles, comb-like plexus structures, and 'empty' ganglia without nerve cells were observed. These general signs of neurodegeneration were paralleled by a decrease of S100-immunoreactive glial elements which may leave the nerve elements unprotected against inflammatory damage (da Silveira et al. 2009; Jabari et al. 2013).

Neuron loss in Chagas' disease is thought to begin in the acute phase after infection with the protozoon Trypanosoma cruzi by direct action of the pathogen, whereas it continues in the chronic phase by (auto)immunologic reactions of the organism (Köberle 1968; Hudson and Hindmarsh 1985; Dutra et al. 2009). However, the parasite does not disappear completely from the afflicted host in most cases (Clayton 2010). During the decades of the chronic phase of Chagas' disease, a megacolon becomes clinically manifest by slowly progressive constipation (de Oliveira et al. 1998). To transform a previously occurring 'functional' motility dysbalance into a permanent megacolon, Köberle (1968) and Meneghelli (2004) suggested that loss of more than half of the colonic enteric neurons is required. Meneghelli (2004) found a $50 \%$ loss of myenteric neurons in small intestinal samples displaying no mega-syndrome. Whereas megaesophagus occurs almost as frequently as megacolon in chronic Chagas' disease, 'megas' of other intestinal regions are rare (Köberle 1968). [By far the most frequently affected organ in chronic Chagas' disease is the heart (Köberle 1968)].

Extensive myenteric neuron loss in chagasic megacolon was shown in a number of studies (Köberle 1968; Fernandez et al. 1992; Adad et al. 2001; Meneghelli 2004; Iantorno et al. 2007). Own results generally confirmed these findings and additionally demonstrated parallel decrease of nerve fibre density in the circular and longitudinal muscle layers (Jabari et al. 2011, 2012b). This was demonstrated both by applying general neuronal and glial (SYN, S 100) as well as specific neuronal markers (see below). Besides general signs of neurodegeneration (see above), we additionally found the few, remaining neurons to be frequently deformed and hyper- or atrophic and to be mostly immunoreactive for nNOS and/or VIP (Fig. 3). Co-application of the pan-neuronal marker $\mathrm{HU}$ enabled us to discriminate the relative increase of the nitrergic/VIP-ergic subpopulation from its absolute decrease (Jabari et al. 2011 in
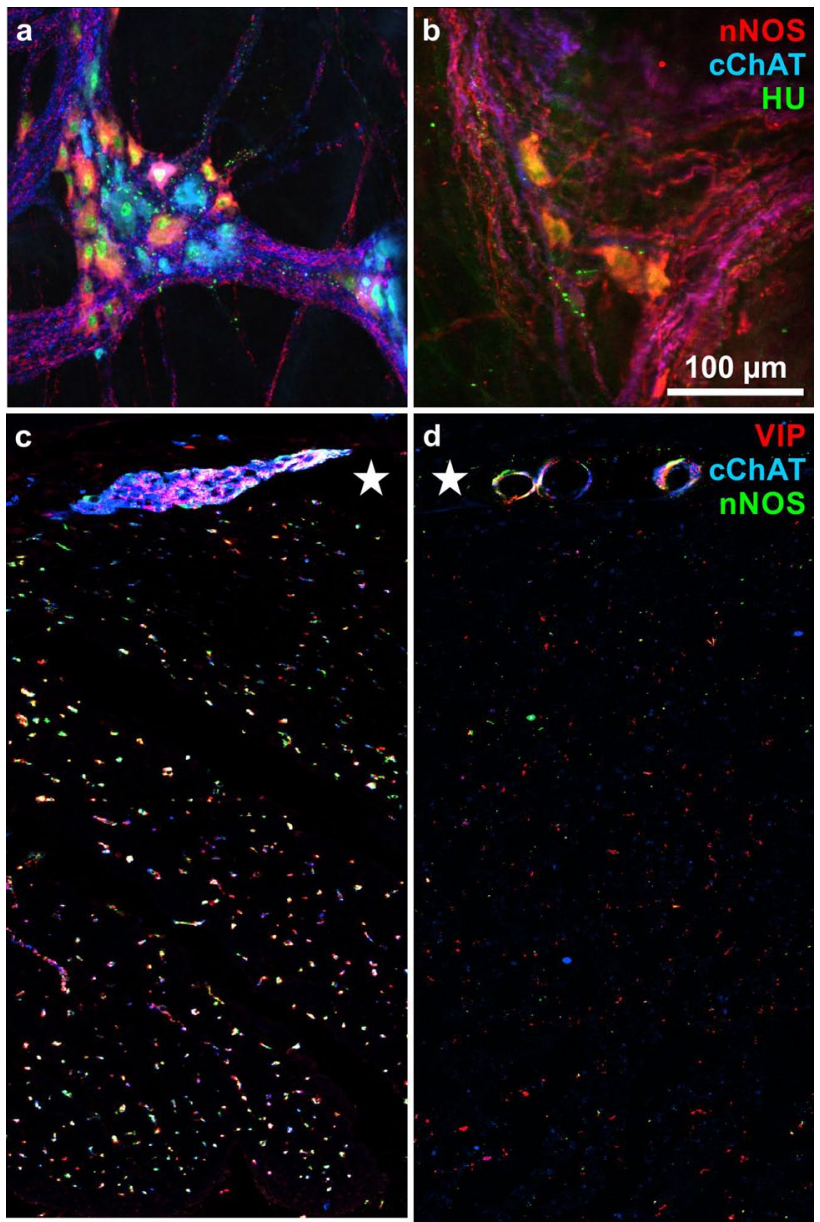
contrast, in chagasic/megacolonic tissues, this proportion increased up to $86 \%$ (Jabari et al. 2011). Even more conspicuously, the fraction of nitrergic neurons co-localizing VIP increased disproportionately. In non-chagasic/nonmegacolonic colon, nNOS/VIP-neurons amounted to only $9 \%$ (Schuy et al. 2011), whereas in chagasic/megacolonic samples, up to $51 \%$ (Jabari et al. 2012b). Generally, these changes in ganglionic composition were paralleled by changes in intramuscular nerve fibre spectrum. Besides a general reduction in nerve fibre density, nerve fibres immunoreactive for nNOS or VIP or both were increased. For example, in control colonic circular muscle, $68 \%$ of nerve fibres were nNOS- and/or VIP-reactive, and this proportion increased from $75 \%$ (in the oral transitional zone) via $84 \%$ (megacolonic zone) up to $87 \%$ (anal zone; Jabari et al. 2012b). In mice infected with Trypanosoma cruzi, nitrergic nerve elements were similarly spared from extensive loss (Ny et al. 1999). Also, with ageing, a relative, although less pronounced increase of nitrergic neurons was described in both animals and humans (Santer 1994; Phillips et al. 2003; Bernard et al. 2009).

Reasons for this partial, selective survival of nitrergic and VIP-ergic nerve elements were discussed (Jabari et al. 2011, 2012b) and will be dealt with below. Consequences of the prevalence of neurons and nerve fibres containing these two inhibitory neurotransmitters (Grider 1989, 1993) seem to allow a casual explanation of the development of a permanently dilated 'megacolon'. However, analysing also the transitional zones directly oral and anal to the dilated, megacolonic segment, only the findings of the oral zone (displaying a less pronounced destruction and loss of cholinergic nerve elements) were in line with this explanation.

In contrast, in the anal zone, the dysbalance between inhibitory (VIP, nNOS containing) and excitatory (cholinergic) nerve elements was most pronounced toward the former; however, this region was not dilated. In other words, the extent of changes demonstrated immunohistochemically by neuronal and glial markers corresponded with the change of calibre along the surgically removed chagasic megacolon only in the oral transitional and the megacolonic zones. They did not correspond in the anal transitional zone. Here, the change of neuro-immunohistochemical parameters toward inhibitory elements is not accompanied by dilation. This suggests that the neuronal dysbalance alone is not sufficient for explaining the chronic dilation, and additional factors must be taken into account.

\section{Chagasic megacolon: smooth muscle and interstitial cells of Cajal (ICC)}

Both the external and the mucosal muscle layers are remarkably thickened in chagasic megacolon (Köberle

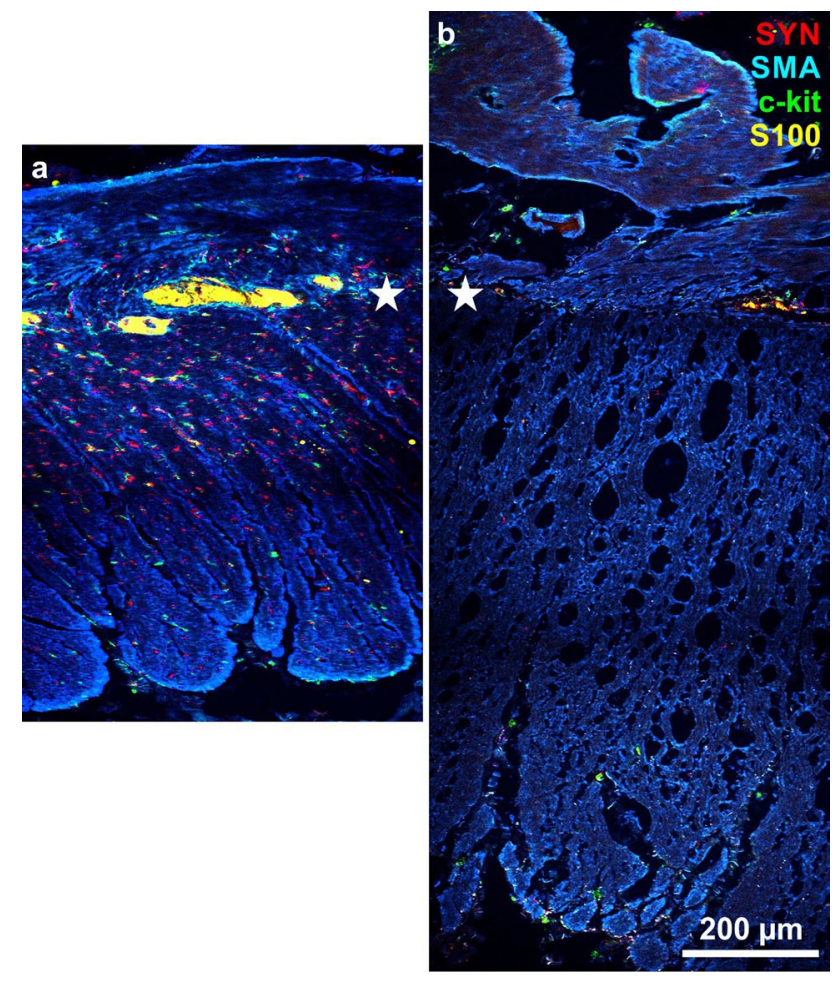

Fig. 4 Cross sections through the muscle coats (adjusted to the plane of the myenteric plexus, asterisks) immunohistochemically quadruple stained for synaptophysin (SYN, red), $\alpha$-smooth muscle actin (SMA, blue), c-kit (green), and S100 (yellow). a control specimen, b chagasic/megacolonic specimen. Note in (b) in contrast to (a): the increased thickness of both muscle layers (blue), the loosened architecture of the muscle tissue (blue), and the decreased density of the other three markers (for details see Jabari et al. 2013)

1968). Permanent dilation of a (colonic) gut segment is accompanied by thickening of its wall. Initially, thickening predominates over dilation, whereas later, as a sign of decompensation, the gut wall distends with the muscle layers becoming thinner (Köberle 1968). Adad et al. (2012) described muscle area thickening in sections of the muscularis propria in chagasic megacolon increasing as much as five times compared to controls. These authors concluded that the development of the dilation is accompanied by muscular hypertrophy. But muscle layer thickening is not only due to an increase of muscle tissue but also to proliferation of connective tissue. Massive fibrosis has been found in chagasic megacolon (Pinheiro et al. 2003; da Silveira et al. 2007; Iantorno et al. 2007; Jabari et al. 2014). Consequently, in the thickened muscle layers of the dilated megacolonic zones, we found a decreased density of SMA together with a loosened architecture of the SMA-stained circular and longitudinal layers (Fig. 4; Jabari et al. 2013). Decreased density of SMA has been found also in other motility disorders, together with a strikingly changed architecture of musculature (Knowles et al. 2004; Wedel 
et al. 2006). The decreased density of SMA and thereby the reduction of contractile elements in the megacolonic zone may be a sign of the massive impairment of motility. Besides, there are also reports that no or non-significant deficiencies of smooth musculature morphology occur in intestinal pseudo-obstruction, Hirschsprung's disease, and idiopathic intractable constipation (Gamba et al. 2004; Knowles et al. 2004; van den Berg et al. 2009).

A decrease of ICCs has been described in chagasic megacolon (Hagger et al. 2000; Matsuda et al. 2009; Adad et al. 2012). Although these cells are seen as contributors in the development of numerous motility disorders (Streutker et al. 2007; Rolle et al. 2007; Adachi et al. 2008; Sanders et al. 2010), their function especially in human gastrointestinal motility is unproven (Sanders et al. 2012).

The contraction of gastrointestinal smooth muscle is supposed to be generated by the common action of at least three electrically coupled cell types, i.e. ICCs, 'non-ICC-interstitial cells' (being immunoreactive for the platelet-derived growth factor receptor $\alpha$ ), and smooth muscle cells. Enteric neurons, hormones, and paracrine substances modulate their contraction (Sanders et al. 2012). Obviously, in chagasic and Hirschsprung's megacolon, the balance between these components is disturbed in different ways (see above and Fig. 2). However, in Hirschsprung's (Gfroerer and Rolle 2013) and Chagas' megacolon (see above), most studies found reduced numbers of ICCs in the hypo- or aganglionic segments. One exception is the study of Horisawa et al. (1998) who found no difference in ICC distribution between aganglionic (Hirschsprung) and intact descending colon. In chagasic megacolon, a close topographical correlation between the change of calibre along the resected specimens and the changes of parameters was observed related to smooth muscle and ICC densities (Jabari et al. 2011, 2012a, b, 2013). Values were lower in dilated and megacolonic, and were higher in non-dilated oral and anal zones (Jabari et al. 2013). That is, decrease in muscle tissue and ICC densities is topographically directly linked with the extent of the mega-syndrome. Thus, changes of these two parameters provide a more consistent explanation for the change of the colonic circumference.

\section{Chagasic megacolon: submucosal neurons and mucosal nerve fibres}

Most studies dealing with chagasic megacolon focused on structures related to motility, and only few presented counts of submucosal neurons in chagasic gut segments (Costa and De Lima Filho 1964; Meneghelli 2004; Iantorno et al. 2007). Our own counts in chagasic/megacolonic submucosal plexus principally confirmed the results of the earliest authors (Costa and De Lima Filho 1964), i.e. in contrast to the massive myenteric neuron loss, the submucosal neuron loss was rather moderate (Jabari et al. 2012a). However, there is a selective loss of neurons also in the two submucosal plexus. Here, neurons co-immunoreactive for CALR and VIP were spared (Jabari et al. 2012a). In the healthy, colonic external and internal submucosal plexus, at the most one-third of neurons is VIP-negative and these neurons degenerated almost completely in chagasic megacolon. Among these VIP-negative neurons, the largest and best known population is the SOM (ChAT/SP)-immunoreactive one (Beyer et al. 2013). Consequently, mucosal nerve fibres immunoreactive for SOM were hardly found, whereas VIP(/CALR)-positive nerve fibres were, though reduced in density, present throughout all megacolonic and transitional zones (Jabari et al. 2012a). Within the mucosa, the muscularis mucosae and the lamina propria displayed diverging changes as to the megacolonic and the anal segments. The lamina propria showed highest layer thickness and lowest densities of nerve fibres, glia, and smooth muscle tissue in the dilated portion itself. In contrast, in the muscularis mucosae, the layer thickness was highest and the nerve/glia densities were lowest in the anal segment thus paralleling results of the (external) muscle coat (Jabari et al. 2014).

Considering the chronic, decades lasting phase of Chagas' disease, it is evident that some vital mucosal structures must be maintained. One of these is the epithelium whose barrier function requires, e.g. cell proliferation and expression of tight junction proteins. Both depend on the action of VIP-ergic submucosal neurons (Neunlist et al. 2003; Toumi et al. 2003). If these VIP-neurons would have died in the course of Chagas' disease, we suggest that these patients could not have survived for decades. In contrast, considering the almost total loss of SOM-neurons in chagasic megacolon, this population seems not to be of vital importance.

\section{Vasoactive intestinal peptide (VIP)}

The difference in proportions of VIP-neurons in the respective plexus reflects the difference in the numbers of surviving neurons in chronic Chagas' disease. That is, $\mathrm{VIP}(/ \mathrm{nNOS})$-neurons are a minority in the healthy myenteric plexus-few myenteric neurons survive in chagasic megacolon (Fig. 3). In contrast, VIP(/CALR)-neurons are a majority in the healthy submucosal plexus - a considerable number of submucosal neurons survive (Fig. 5). Above, we discussed our suggestions as to quite different consequences of the survival of myenteric and submucosal VIPneurons. The myenteric VIP-neurons may contribute to the development of the megacolon, whereas the submucosal VIP-neurons may enable the patients to survive by maintaining the epithelial barrier. 


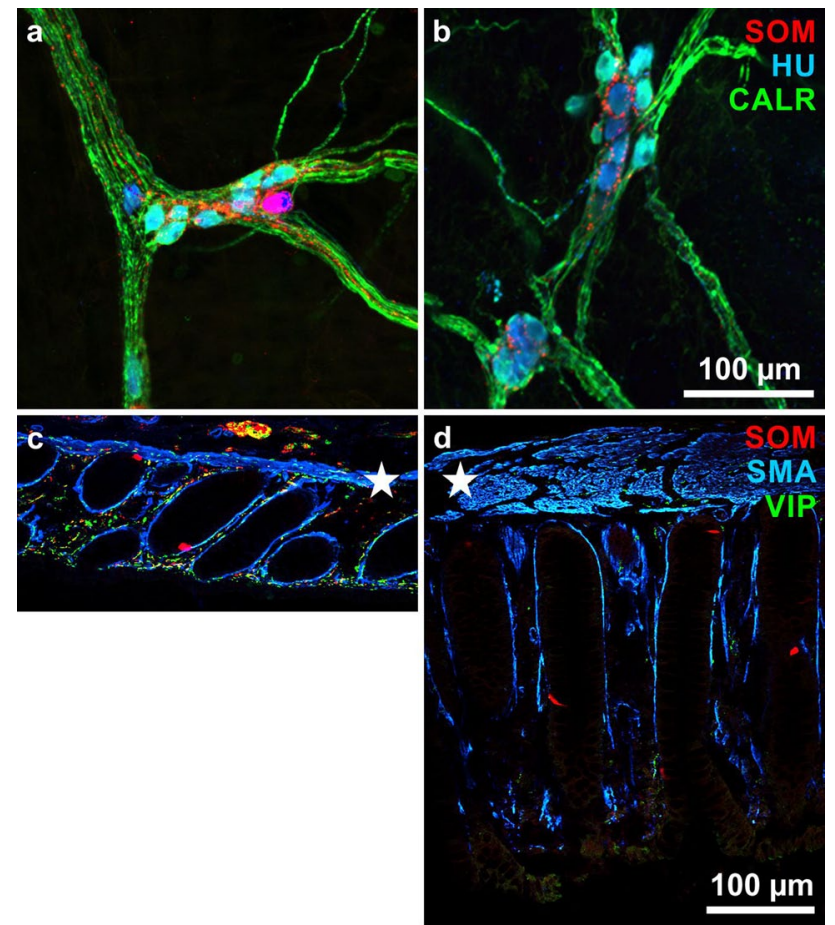

Fig. 5 a, b External submucosal ganglia in wholemounts immunohistochemically triple stained for somatostatin (SOM, red), the human neuronal protein $\mathrm{Hu} \mathrm{C} / \mathrm{D}$ (HU, blue), and calretinin (CALR, green). a is from a non-chagasic/non-megacolonic ('control'), b from a chagasic/megacolonic specimen. Note that in both cases, the ganglia display quite similar appearance; in (b), there is no red (SOM-positive) neuron. c, d Mucosal layers in cross sections (with adjusted muscularis mucosae, asterisks) triple stained for SOM (red), $\alpha$-smooth muscle actin (SMA, blue), and vasoactive intestinal peptide (VIP, green). Note the increased thickness and the decreased nerve fibre density with a complete loss of red (SOM-reactive) nerve fibres in (d) in contrast to (c). SOM-positive enteroendocrine cells (red patches) are present in both (c) and (d)

One reason for survival of these neurons may be VIP itself. It is well established that this peptide is neuroprotective (Ekblad and Bauer 2004; Pozo and Delgado 2004; Brenneman 2007; Arranz et al. 2008; Ben-Horin and Chowers 2008). Additionally, also nitric oxide was able to promote enteric neuronal survival in culture (Sandgren et al. 2003). We suggest that VIP may protect both the submucosal VIP-neurons, acting on epithelial cells, and the myenteric VIP-neurons, acting together with nNOS as inhibitory motor neurons.

In conclusion, we suggest that during megacolon formation in chronic Chagas' disease, neuron loss alone does not explain completely the loss of motility and the subsequent calibre change. Other cells and tissues (e.g. ICCs, smooth muscle cells) may be primarily damaged as well. As to the survival of patients despite the obvious changes in the enteric nervous system, VIP may play a key role due to its neuroprotective and neuroeffectory functions.
Acknowledgments We especially thank Winfried Neuhuber (Erlangen) for permanent support of our investigations and valuable help in preparing the manuscript. The excellent technical assistance of Karin Löschner and Stefanie Link as well as Anita Hecht, Andrea Hilpert, Hedwig Symowski, and Inge Zimmermann (all Erlangen, Germany) is gratefully acknowledged. Our works were supported by funds from CNPq (Conselho Nacional de Desenvolvimento Científico e Tecnológico), FIOCRUZ (FundaçAão Oswaldo Cruz), PAPES V (Programa de Apoio a Pesquisa Estratégica em Saúde), and Deutsche Forschungsgemeinschaft (BR 1815/4-1).

Open Access This article is distributed under the terms of the Creative Commons Attribution License which permits any use, distribution, and reproduction in any medium, provided the original author(s) and the source are credited.

\section{References}

Adachi Y, Ishii Y, Yoshimoto M, Yoshida Y, Endo T, Yamamoto H, Akashi H, Imai K, Shinomura Y, Kato Y (2008) Phenotypic alteration of interstitial cells of Cajal in idiopathic sigmoid megacolon. J Gastroenterol 43:626-631

Adad SJ, Cancado CG, Etchebehere RM, Teixeira VP, Gomes UA, Chapadeiro E, Lopes ER (2001) Neuron count reevaluation in the myenteric plexus of chagasic megacolon after morphometric neuron analysis. Virchows Arch 438:254-258

Adad SJ, Silva GB, Jammal AA (2012) The significantly reduced number of interstitial cells of Cajal in chagasic megacolon (CM) patients might contribute to the pathophysiology of CM. Virchows Arch 461:385-392

Arranz A, Abad C, Juarranz Y, Leceta J, Martinez C, Gomariz RP (2008) Vasoactive intestinal peptide as a healing mediator in Crohn's disease. NeuroImmunoModulation 15:46-53

Auerbach L (1862) Ueber einen Plexus myentericus, einen bisher unbekannten ganglio-nervösen Apparat im Darmkanal der Wirbelthiere. In: Morgenstern, Breslau, pp 1-13

Beck M, Schlabrakowski A, Schrödl F, Neuhuber W, Brehmer A (2009) ChAT and NOS in human myenteric neurons: co-existence and co-absence. Cell Tissue Res 338:37-51

Ben-Horin S, Chowers Y (2008) Neuroimmunology of the gut: physiology, pathology, and pharmacology. Curr Opin Pharmacol 8:490-495

Bernard CE, Gibbons SJ, Gomez-Pinilla PJ, Lurken MS, Schmalz PF, Roeder JL, Linden D, Cima RR, Dozois EJ, Larson DW, Camilleri M, Zinsmeister AR, Pozo MJ, Hicks GA, Farrugia G (2009) Effect of age on the enteric nervous system of the human colon. Neurogastroenterol Motil 21:746-754

Beuscher N, Jabari S, Strehl J, Neuhuber W, Brehmer A (2014) What neurons hide behind calretinin immunoreactivity in the human gut? Histochem Cell Biol 141:393-405

Beyer J, Jabari S, Rau TT, Neuhuber W, Brehmer A (2013) Substance $\mathrm{P}$ - and choline acetyltransferase-immunoreactivities in somatostatin-containing, human submucosal neurons. Histochem Cell Biol 140:157-167

Blair PJ, Bayguinov Y, Sanders KM, Ward SM (2012) Interstitial cells in the primate gastrointestinal tract. Cell Tissue Res 350: 199-213

Bodian M, Stephens FD, Ward BCH (1949) Hirschsprung's disease and idiopathic megacolon. Lancet 253:6-11

Brehmer A (2006) Structure of enteric neurons. Adv Anat Embryol Cell Biol 186:1-94

Brehmer A, Schrödl F, Neuhuber W (1999) Morphological classifications of enteric neurons-100 years after Dogiel. Anat Embryol (Berl) 200:125-135 
Brehmer A, Blaser B, Seitz G, Schrödl F, Neuhuber W (2004a) Pattern of lipofuscin pigmentation in nitrergic and non-nitrergic, neurofilament immunoreactive myenteric neuron types of human small intestine. Histochem Cell Biol 121:13-20

Brehmer A, Croner R, Dimmler A, Papadopoulos T, Schrödl F, Neuhuber W (2004b) Immunohistochemical characterization of putative primary afferent (sensory) myenteric neurons in human small intestine. Auton Neurosci 112:49-59

Brehmer A, Lindig TM, Schrödl F, Neuhuber W, Ditterich D, Rexer M, Rupprecht H (2005) Morphology of enkephalin-immunoreactive myenteric neurons in the human gut. Histochem Cell Biol 123:131-138

Brehmer A, Schrödl F, Neuhuber W (2006) Morphology of $\mathrm{VIP} / \mathrm{nNOS}$-immunoreactive myenteric neurons in the human gut. Histochem Cell Biol 125:557-565

Brehmer A, Rupprecht H, Neuhuber W (2010) Two submucosal nerve plexus in human intestines. Histochem Cell Biol 133:149-161

Brenneman DE (2007) Neuroprotection: a comparative view of vasoactive intestinal peptide and pituitary adenylate cyclase-activating polypeptide. Peptides 28:1720-1726

Chandrasekharan B, Nezami BG, Srinivasan S (2013) Emerging neuropeptide targets in inflammation: NPY and VIP. Am J Physiol Gastrointest Liver Physiol 304:G949-G957

Clayton J (2010) Chagas disease 101. Nature 465:S4-S5

Costa RB, De Lima Filho EC (1964) The submucous and myenteric plexuses of the human colon in chagas' disease. Rev Inst Med Trop Sao Paulo 6:211-218

da Silveira AB, Adad SJ, Correa-Oliveira R, Furness JB, D'Avila Reis D (2007) Morphometric study of eosinophils, mast cells, macrophages and fibrosis in the colon of chronic chagasic patients with and without megacolon. Parasitology 134:789-796

da Silveira AB, Freitas MA, de Oliveira EC, Neto SG, Luquetti AO, Furness JB, Correa-Oliveira R, Reis D (2009) Glial fibrillary acidic protein and S-100 colocalization in the enteroglial cells in dilated and nondilated portions of colon from chagasic patients. Human Pathol 40:244-251

De Biscop G (1949) Über pathologische Veränderungen am Auerbachschen Plexus bei Megacolon. Z Zellforsch Mikrosk Anat 34:141-159

de Oliveira RB, Troncon LE, Dantas RO, Menghelli UG (1998) Gastrointestinal manifestations of Chagas' disease. Am J Gastroenterol 93:884-889

Dutra WO, Menezes CA, Villani FN, da Costa GC, da Silveira AB, Reis D, Gollob KJ (2009) Cellular and genetic mechanisms involved in the generation of protective and pathogenic immune responses in human Chagas disease. Mem Inst Oswaldo Cruz 104(Suppl 1):208-218

Dzienis-Koronkiewicz E, Debek W, Chyczewski L (2005) Use of synaptophysin immunohistochemistry in intestinal motility disorders. Eur J Pediatr Surg 15:392-398

Ekblad E, Bauer AJ (2004) Role of vasoactive intestinal peptide and inflammatory mediators in enteric neuronal plasticity. Neurogastroenterol Motil 16(Suppl 1):123-128

Farthing MJ (2006) Antisecretory drugs for diarrheal disease. Dig Dis 24:47-58

Fernandez A, Hontebeyrie M, Said G (1992) Autonomic neuropathy and immunological abnormalities in Chagas' disease. Clin Auton Res 2:409-412

Ferri GL, Probert L, Cocchia D, Michetti F, Marangos PJ, Polak JM (1982) Evidence for the presence of S-100 protein in the glial component of the human enteric nervous system. Nature 297:409-410

Furness JB (2006) The enteric nervous system. Blackwell, Oxford

Furness JB, Costa M (1987) The enteric nervous system. Churchill Livingstone, Edinburgh
Gamba E, Carr NJ, Bateman AC (2004) Deficient alpha smooth muscle actin expression as a cause of intestinal pseudo-obstruction: fact or fiction? J Clin Pathol 57:1168-1171

Ganns D, Schrödl F, Neuhuber W, Brehmer A (2006) Investigation of general and cytoskeletal markers to estimate numbers and proportions of neurons in the human intestine. Histol Histopathol 21:41-51

Gfroerer S, Rolle U (2013) Interstitial cells of Cajal in the normal human gut and in Hirschsprung disease. Pediatr Surg Int 29:889-897

Grider JR (1989) Identification of neurotransmitters regulating intestinal peristaltic reflex in humans. Gastroenterology 97:1414-1419

Grider JR (1993) Interplay of VIP and nitric oxide in regulation of the descending relaxation phase of peristalsis. Am J Physiol 264:G334-G340

Gulbransen BD, Sharkey KA (2012) Novel functional roles for enteric glia in the gastrointestinal tract. Nat Rev Gastroenterol Hepatol 9:625-632

Hagger R, Finlayson C, Kahn F, De Oliveira R, Chimelli L, Kumar D (2000) A deficiency of interstitial cells of Cajal in Chagasic megacolon. J Auton Nerv Syst 80:108-111

Hanani M, Fellig Y, Udassin R, Freund HR (2004) Age-related changes in the morphology of the myenteric plexus of the human colon. Auton Neurosci 113:71-78

Horisawa M, Watanabe Y, Torihashi S (1998) Distribution of c-Kit immunopositive cells in normal human colon and in Hirschsprung's disease. J Pediatr Surg 33:1209-1214

Howard ER (1972) Hirschsprung's disease: a review of the morphology and physiology. Postgrad Med J 48:471-477

Hudson L, Hindmarsh PJ (1985) The relationship between autoimmunity and Chagas' disease: causal or coincidental? Curr Top Microbiol Immunol 117:167-177

Huizinga JD, Thuneberg L, Klüppel M, Malysz J, Mikkelsen HB, Bernstein A (1995) W/kit gene required for interstitial cells of Cajal and for intestinal pacemaker activity. Nature 373:347-349

Iantorno G, Bassotti G, Kogan Z, Lumi CM, Cabanne AM, Fisogni S, Varrica LM, Bilder CR, Munoz JP, Liserre B, Morelli A, Villanacci V (2007) The enteric nervous system in chagasic and idiopathic megacolon. Am J Surg Pathol 31:460-468

Jabari S, da Silveira AB, de Oliveira EC, Neto SG, Quint K, Neuhuber W, Brehmer A (2011) Partial, selective survival of nitrergic neurons in chagasic megacolon. Histochem Cell Biol 135:47-57

Jabari S, da Silveira ABM, deOliveira EC, Neto SG, Quint K, Neuhuber W, Brehmer A (2012a) Selective survival of calretinin- and vasoactive-intestinal-peptide-containing nerve elements in human chagasic submucosa and mucosa. Cell Tissue Res 349:473-481

Jabari S, da Silveira AB, de Oliveira EC, Quint K, Neuhuber W, Brehmer A (2012b) Preponderance of inhibitory versus excitatory intramuscular nerve fibres in human chagasic megacolon. Int $\mathbf{J}$ Colorectal Dis 27:1181-1189

Jabari S, da Silveira AB, de Oliveira EC, Quint K, Wirries A, Neuhuber W, Brehmer A (2013) Interstitial cells of Cajal: crucial for the development of megacolon in human Chagas' disease? Colorectal Dis 15:e592-e598

Jabari S, da Silveira ABM, de Oliveira EC, Quint K, Wirries A, Neuhuber W, Brehmer A (2014) Mucosal layers and related nerve fibres in non-chagasic and chagasic human colon-a quantitative immunohistochemical study. Cell Tissue Res. doi:10.1007/ s00441-014-1934-5

Kapp S, Schrödl F, Neuhuber W, Brehmer A (2006) Chemical coding of submucosal type $\mathrm{V}$ neurons in porcine ileum. Cells Tissues Organs 184:31-41

Karaki SI, Kuwahara A (2004) Regulation of intestinal secretion involved in the interaction between neurotransmitters and prostaglandin E2. Neurogastroenterol Motil 16(Suppl 1):96-99 
Knowles CH, Silk DB, Darzi A, Veress B, Feakins R, Raimundo AH, Crompton T, Browning EC, Lindberg G, Martin JE (2004) Deranged smooth muscle alpha-actin as a biomarker of intestinal pseudo-obstruction: a controlled multinational case series. Gut 53:1583-1589

Köberle F (1968) Chagas' disease and Chagas' syndromes: The pathology of American trypanosomiasis. Adv Parasitol 6:63-116

Krishnamurthy S, Schuffler MD, Rohrmann CA, Pope CE 2nd (1985) Severe idiopathic constipation is associated with a distinctive abnormality of the colonic myenteric plexus. Gastroenterology 88:26-34

Kustermann A, Neuhuber W, Brehmer A (2011) Calretinin and somatostatin immunoreactivities label different human submucosal neuron populations. Anat Rec (Hoboken) 294:858-869

Lindig TM, Kumar V, Kikinis R, Pieper S, Schrödl F, Neuhuber WL, Brehmer A (2009) Spiny versus stubby: 3D reconstruction of human myenteric (type I) neurons. Histochem Cell Biol 131:1-12

Maeda H, Yamagata A, Nishikawa S, Yoshinaga K, Kobayashi S, Nishi K, Nishikawa S (1992) Requirement of c-kit for development of intestinal pacemaker system. Development 116:369-375

Margolis KG, Gershon MD (2009) Neuropeptides and inflammatory bowel disease. Curr Opin Gastroenterol 25:503-511

Matsuda NM, Miller SM, Evora PR (2009) The chronic gastrointestinal manifestations of Chagas disease. Clinics 64:1219-1224

Meissner G (1857) Über die Nerven der Darmwand. Z Ration Med N F 8:364-366

Meneghelli UG (2004) Chagasic enteropathy. Rev Soc Bras Med Trop 37:252-260

Murphy EM, Defontgalland D, Costa M, Brookes SJ, Wattchow DA (2007) Quantification of subclasses of human colonic myenteric neurons by immunoreactivity to $\mathrm{Hu}$, choline acetyltransferase and nitric oxide synthase. Neurogastroenterol Motil 19:126-134

Neunlist M, Toumi F, Oreschkova T, Denis M, Leborgne J, Laboisse CL, Galmiche JP, Jarry A (2003) Human ENS regulates the intestinal epithelial barrier permeability and a tight junction-associated protein ZO-1 via VIPergic pathways. Am J Physiol Gastrointest Liver Physiol 285:G1028-G1036

Ny L, Persson K, Larsson B, Chan J, Weiss LM, Wittner M, Huang H, Tanowitz HB (1999) Localization and activity of nitric oxide synthases in the gastrointestinal tract of Trypanosoma cruzi-infected mice. J Neuroimmunol 99:27-35

Phillips RJ, Kieffer EJ, Powley TL (2003) Aging of the myenteric plexus: neuronal loss is specific to cholinergic neurons. Auton Neurosci 106:69-83

Phillips RJ, Hargrave SL, Rhodes BS, Zopf DA, Powley TL (2004) Quantification of neurons in the myenteric plexus: an evaluation of putative pan-neuronal markers. J Neurosci Methods 133:99-107

Pinheiro SW, Rua AM, Etchebehere RM, Cancado CG, Chica JE, Lopes ER, Adad SJ (2003) Morphometric study of the fibrosis and mast cell count in the circular colon musculature of chronic Chagas patients with and without megacolon. Rev Soc Bras Med Trop 36:461-466

Pozo D, Delgado M (2004) The many faces of VIP in neuroimmunology: a cytokine rather a neuropeptide? FASEB J 18:1325-1334

Ribeiro U, Safatle-Ribeiro AV, Habr-Gama A, Gama-Rodrigues J, Sohn J, Reynolds J (1998) Effect of chagas' disease on nitric oxide-containing neurons in severely affected and unaffected intestine. Dis Colon Rectum 41:1411-1417

Rolle U, Piaseczna-Piotrowska A, Puri P (2007) Interstitial cells of Cajal in the normal gut and in intestinal motility disorders of childhood. Pediatr Surg Int 23:1139-1152

Rumessen JJ, Thuneberg L (1996) Pacemaker cells in the gastrointestinal tract: interstitial cells of Cajal. Scand J Gastroenterol Suppl 216:82-94
Sanders KM, Hwang SJ, Ward SM (2010) Neuroeffector apparatus in gastrointestinal smooth muscle organs. J Physiol 588:4621-4639

Sanders KM, Koh SD, Ro S, Ward SM (2012) Regulation of gastrointestinal motility-insights from smooth muscle biology. Nat Rev Gastroenterol Hepatol 9:633-645

Sandgren K, Lin Z, Fex Svenningsen A, Ekblad E (2003) Vasoactive intestinal peptide and nitric oxide promote survival of adult rat myenteric neurons in culture. J Neurosci Res 72:595-602

Santer RM (1994) Survival of the population of NADPH-diaphorase stained myenteric neurons in the small intestine of aged rats. J Auton Nerv Syst 49:115-121

Schabadasch A (1930) Intramurale Nervengeflechte des Darmrohrs. Z Zellforsch Mikrosk Anat 10:320-385

Schuffler MD, Jonak Z (1982) Chronic idiopathic intestinal pseudoobstruction caused by a degenerative disorder of the myenteric plexus: the use of Smith's method to define the neuropathology. Gastroenterology 82:476-486

Schuffler MD, Bird TD, Sumi SM, Cook A (1978) A familial neuronal disease presenting as intestinal pseudoobstruction. Gastroenterology 75:889-898

Schuffler MD, Leon SH, Krishnamurthy S (1985) Intestinal pseudoobstruction caused by a new form of visceral neuropathy: palliation by radical small bowel resection. Gastroenterology 89:1152-1156

Schuy J, Schlabrakowski A, Neuhuber W, Brehmer A (2011) Quantitative estimation and chemical coding of spiny type I neurons in human intestines. Cells Tissues Organs 193:195-206

Smith B (1972) The neuropathology of the alimentary tract, London

Stach W (1977) The external submucous plexus (Schabadasch) in the small intestine of the swine. I. Form, structure and connections of ganglia and nerve cells. Z Mikrosk Anat Forsch 91:737-755

Streutker CJ, Huizinga JD, Driman DK, Riddell RH (2007) Interstitial cells of Cajal in health and disease. Part I: normal ICC structure and function with associated motility disorders. Histopathology 50:176-189

Takaki M (2003) Gut pacemaker cells: the interstitial cells of Cajal (ICC). J Smooth Muscle Res 39:137-161

Thuneberg L (1982) Interstitial cells of Cajal: intestinal pacemaker cells? Adv Anat Embryol Cell Biol 71:1-130

Timmermans JP, Barbiers M, Scheuermann DW, Bogers JJ, Adriaensen D, Fekete E, Mayer B, Van Marck EA, De Groodt-Lasseel MHA (1994) Nitric oxide synthase immunoreactivity in the enteric nervous system of the developing human digestive tract. Cell Tissue Res 275:235-245

Timmermans JP, Hens J, Adriaensen D (2001) Outer submucous plexus: an intrinsic nerve network involved in both secretory and motility processes in the intestine of large mammals and humans. Anat Rec 262:71-78

Toumi F, Neunlist M, Cassagnau E, Parois S, Laboisse CL, Galmiche JP, Jarry A (2003) Human submucosal neurones regulate intestinal epithelial cell proliferation: evidence from a novel co-culture model. Neurogastroenterol Motil 15:239-242

Truelove SC (1966) Movements of the large intestine. Physiol Rev 46:457-512

van den Berg MM, Di Lorenzo C, Mousa HM, Benninga MA, Boeckxstaens GE, Luquette M (2009) Morphological changes of the enteric nervous system, interstitial cells of cajal, and smooth muscle in children with colonic motility disorders. J Pediatr Gastroenterol Nutr 48:22-29

Vanderwinden JM, Rumessen JJ, Liu H, Descamos D, De Laet MH, Vanderhaeghen JJ (1996) Interstitial cells of Cajal in human colon and in Hirschsprung's disease. Gastroenterology 111:901-910

Ward SM, Sanders KM, Hirst GD (2004) Role of interstitial cells of Cajal in neural control of gastrointestinal smooth muscles. Neurogastroenterol Motil 16(Suppl 1):112-117 
Wedel T, Van Eys GJ, Waltregny D, Glenisson W, Castronovo V, Vanderwinden JM (2006) Novel smooth muscle markers reveal abnormalities of the intestinal musculature in severe colorectal motility disorders. Neurogastroenterol Motil 18:526-538
Wiedenmann B, Franke WW (1985) Identification and localization of synaptophysin, an integral membrane glycoprotein of $\mathrm{Mr} 38,000$ characteristic of presynaptic vesicles. Cell 41:1017-1028 